\title{
A CRITICAL APPROACH TO AMERICAN CINEMA THROUGH SPORT FILMS: THE BLIND SIDE
}

\author{
Juan Pablo Osman \\ osmanj@uninorte.edu.co \\ Universidad del Norte, Colombia
}

Abstract

Sport and Film have been widely discussed as separate areas of study. However, the relationship between both fields has not been approached extensively. The main objective of this research is to analyze what is the ideological agenda behind the film The Blind Side (2009) framing the research around the last sequence of the film. This study is positioned under a critic and a de-colonial perspective and using as its main methodology textual analysis. The central argument of this investigation is there is an ideological agenda in The Blind Side that reproduces and aims to maintain dominant and postcolonial logics and structures.

KEYwords: film, sport, sport films, social communication, ideology, postcolonialism, de-colonialism.

\section{ANÁLISIS CRÍTICO DEL CINE ESTADOUNIDENSE DE GÉNERO DEPORTIVO: THE BLIND SIDE}

\section{RESUMEN}

El deporte y el cine han sido ampliamente discutidos como áreas separadas de estudio. Sin embargo, la relación entre ambos campos no se ha abordado ampliamente. El objetivo principal de esta investigación es analizar cuál es la agenda ideológica detrás de la película The Blind Side (2009) enmarcando la investigación en torno a la última secuencia de la película. Este estudio se posiciona bajo una perspectiva crítica y decolonial y utiliza como metodología principal el análisis textual. El argumento central de esta investigación es que hay una agenda ideológica en The Blind Side que reproduce y apunta a mantener las lógicas y estructuras postcolonialistas dominantes en la sociedad.

Palabras clave: cine, deporte, cine deportivo, comunicación social, ideología, postcolonialismo, decolonialismo. 


\section{INTRODUCTION}

Three, two, one... Movement

American films have been and continue to be hugely influential in other societies with very different cultural, social, and political characteristics from the United States society. Film data researcher Stephen Follows (2017) published a study where he showed that since 2003 revenue of American films overseas has been more significant than the domestic box office of these same films inside the United States. Even more interesting is to observe how this difference between local and overseas revenue has been increasing throughout the years with an almost constant tendency. In summary, American cinema still has a great impact outside the U.S. If we observe this issue specifically in Latin America, we can see how in 2017 amongst 10 countries (Argentina, Brazil, Bolivia, Chile, Colombia, Ecuador, Mexico, Peru, Uruguay, and Venezuela) only Argentina (one film) and Uruguay (two films) had in their lists of the ten most-seen films of the year non-American productions (Box Office Mojo, 2007). These numbers demonstrate American films have been shaping and structuring our filmic culture and continue doing so. Taking into consideration these statistics, a crucial question would be what are the cultural and social repercussions of this dominancy and hegemony of American cinemas in societies located outside the American center? What is the potential sociocultural impact of these narratives? Are we talking here about postcolonial discourses that keep making invisible certain voices of the global South?

When the film projector turned on for the first time, humankind started looking at itself in a completely different way. The lights, the shadows, the shapes of an unreal reality -or real unreality- appeared in front of us like never before: in movement, movement, and more movement, a movement that, in addition, was there but at the same time was not there. The concept of representation had changed forever with the arrival to our lives of that train driven by the Lumière brothers.

Humans fell in love with the big screen feeling the entire world was there and the big screen paid back this love offering more characters, landscapes, sounds, colors; sensorial, emotional and mental experiences, stories and more stories, in summary, more and more world.

This love reached every single corner of the Earth and got transformed into fascination, the whole planet was in the big screen, the big screen was in the entire planet. This relationship became so strong and intense that it started becoming subject of interest for all those disciplines that study human behavior. Psychologists, sociologists, anthropologists began to analyze and try to comprehend the relationship between film and society. Bywater and Sobchack (1989) state there are three main traditions approaching the relationship between film and society. One based on the effects on human behavior, a second one focused on cinema as a reflection of an individual or collective identity, and third one assumes cinema as a social institution.

A group of theorists establishes a fourth dimension and analyze cinema as a medium of social communication (Pardo, 1998). Here I would like to highlight the concepts brought by British professor Andrew Tudor (1975) who points out 
that cinema has the qualities of an act of communication, accomplishing two big functions: socialization and legitimization. According to Tudor, films must be considered as cultural models.

None of this involves conceiving the media as direct causes of behavioral patterns and social developments. As we have already seen the evidence is overwhelmingly in favor of more indirect relations. Nor do people automatically respond to culture in the prescribed manner in stimulus-response fashion: the process is creative in that people use culture more or less consciously and in a variety of ways. There seem to be two main levels to this process, one making rather stronger claims tan the other. The former is the process in which the movies, as part of our culture, provide us with a cultural 'map' through which we can interpret the world. The latter is the more general process whereby the movies are used to justify or legitimate beliefs, actions, and ideas. (p. 271)

It appears hugely relevant for this research to assume cinema under this perspective brought by Tudor that defines cinema is an act of communication that allows us to socialize and, at the same time, legitimize our points of view. According to Tudor films should be considered as cultural models.

Taking into account this framework, this research has the objective to explore the film The Blind Side as cultural model using a critical and de-colonial perspective standing in the global South. The research aims to explore the ideological agenda underlying this filmic text, specifically the last sequence of the film to explore what kind of points of view are being socialized and legitimized through this moving picture. The object of study will be an American sport film since this kind of films are extremely appropriate to approach this area of knowledge through this lens, as will be explained below. The study will be developed establishing a qualitative textual analysis with five ideological categories related to class, gender, body, race, and social structure.

The Blind Side is a very interesting object of study since it has been the most successful sport film in the past decade. The film has had a worldwide gross of more than U\$300 million and it is on the top-500 list of the most grossing films in history. The film was not only an economic achievement, it also received critical acclaim during 2010, obtaining an Academy Award nomination for Best Motion Picture of the Year, an Academy Award for Best Performance by an Actress in a Leading Role, and a Golden Globe for Best Performance by an Actress in a Motion Picture -Drama. Besides, $66 \%$ of the "critic reviews" on the website Rotten Tomatoes are positive and 90\% of the "audience reviews" are positive (Rotten Tomatoes, 2019). The Blind Side can be considered an authentic product of contemporary globalized popular culture. 
Frankfurt School analyzed the potential repercussions that could arise in the dialogue between media and society and the ideological agenda that could be underlying in this relationship as a mechanism that could guarantee an individual committed with a capitalist society and who worked for the long-lasting of this kind of system and sociopolitical model.

The Critical Theory has a huge connection with materialist Marxism and, therefore, his aim is to produce changes in the political and practical dynamics of society. This can be understood taking into consideration two main reasons: first, Marxist-Engelsist thinking considered philosophy should have repercussions in the practice, and second, under this perspective, the materialist vision designed an ideological and political path to accomplish this practical character of philosophy.

Between 1944 and 1947 Adorno and Horkheimer (2002) wrote the article "The culture industry: enlightenment as mass deception" published in the book "Dialectic of enlightenment. Philosophical fragments". This article expresses a very critical and pessimistic view regarding mass media (film, radio, photography), what they called "The Industry", and the way they interpreted it was extending its influence in the Western societies since the end of First World War. Adorno and Horkheimer especially focused their analysis in the entertainment industry (amusement) in the United States. In this text, Adorno and Horkheimer criticized mass media and established a straight relationship between media and the market.

Amusement under late capitalism is the prolongation of work. It is sought after as an escape from the mechanized work process, and to recruit strength in order to be able to cope with it again. But at the same time mechanization has such power over a man's leisure and happiness, and so profoundly determines the manufacture of amusement goods, that his experiences are inevitably afterimages of the work process itself. The ostensible content is merely a faded foreground; what sinks in is the automatic succession of standardized operations. What happens at work, in the factory, or in the office can only be escaped from by approximation to it in one's leisure time. All amusement suffers from this incurable malady. Pleasure hardens into boredom because, if it is to remain pleasure, it must not demand any effort and therefore moves rigorously in the worn grooves of association. No independent thinking must be expected from the audience: the product prescribes every reaction: not by its natural structure (which collapses under reflection), but by signals. Any logical connection calling for mental effort is painstakingly avoided. (p. 109)

The positions expressed by Adorno and Horkheimer were extremely radical, not recognizing any artistic value in film, radio or photography and they considered these disciplines as pure collective amusement. Clearly, this approach can be totally revaluated today. These three mass media have developed in such way that we have been able to see in their content artistic values standing away of the pure collective amusement. However, it is interesting to observe how the statements proposed by Adorno and Horkheimer are still valid in some narratives of these media and in others that appeared after their article was written such as television, videogames, and multimedia-digital content. 
Under these notions, this research wishes to take some of the thoughts and ideas expressed by Adorno and Horkheimer and analyze their relevance in a contemporary context. Specifically, bringing these notions to observe American cinema, particularly American sport films from the global South, postcolonial, de-colonial point of view.

\section{The De-Colonial Perspective}

Under this context and bringing Tudor back to our discussion, the following question emerges: What are the possible social and cultural connotations of this hegemonic presence of American cinema in other societies? The way we understand media is connected to the logics of Western civilization and neglects how media functions in the global South. There is not a recognition that millions of people outside the West have played a key part in the history of the development of media and the relationship between society and mass media. This narrow vision establishes the postcolonial issue (Shome, 2016). It appears relevant to recognize " $t$ t $]$ he current received history of media in the West as being linked to colonialism and postcolonial inequalities" (p. 2).

At this point, it is important to discuss where do these concepts of global South, postcolonial, and de-colonialism come from? Portuguese sociologist Boaventura de Sousa Santos (2016) defines global South as a metaphor, not a geographical concept. Santos explains global South is a condition that describes the suffering caused by colonialism and capitalism on the global level, but at the same times plays a resistance against that suffering, having an anti-imperialist, anticolonialism, anti-patriarchal understanding of society. Santos also makes it clear that this South is expressed "in the form of excluded, silenced and marginalized populations, such as undocumented immigrants, the unemployed, ethnic or religious minorities, and victims of sexism, homophobia, racism and islamophobia" (p. 19). Based on these thoughts, Santos assures this metaphoric South has its main base in postcolonialism. "[p]ostcolonialism claims that colonialism did not end with the end of historical colonialism. There are other ways through which occupation continues, not necessarily through foreign occupation, tutelage and the prohibition of a state formation" (p. 18).

Mignolo (2007) highlights how since 1998 the modernity/coloniality project at Duke University and University of North Carolina has been meeting discussing this topic. Mignolo reminds us how Peruvian sociologist and political theorist Aníbal Quijano since the 1970s started reflecting around the dependency theory and discussing the periphery-center relationship in political and economic terms. In 1977, Argentinian philosopher Enrique Dussel started thinking of knowledge as a crucial element to be included in this debate, taking the reflection further and beyond the economic and political spectrum.

It is interesting to see how Dussel (2002) draws a line connecting Marxism, Critical Theory, and De-colonialiasm. Dussel argues how Marx built his entire theoretical insight around a marginalized sector of society: proletarians. In addition, 
even though Dussel recognizes Marx was not interested in the consciousness or individuality of this segment of the population, the Argentinian thinker states this was revolutionary due to the intention of making visible the invisible subjects of society. We could say here we can find the seeds of de-colonialism. The Marxist project had a clear objective regarding theory as the base for changes in practical life and, as we will see, de-colonialism also pretends to take theory to practical changes in sociopolitical life. We have already described how Marxism influenced the Critical Theory and now we will try to illustrate the strings that attach Critical Theory and de-colonialism. In 1989, Quijano introduced the concept of de-coloniality and stated that if power, economy, and knowledge were colonized, they had to be de-colonized. At this point, it is important to differentiate postcolonialism from de-coloniality.

[t]he critique of the modern notion of Totality doesn't lead necessarily to postcoloniality, but to de-coloniality (...) de-colonial shift, in other words, is a project of de-linking while post-colonial criticism and theory is a project of scholarly transformation within the academy. (Mignolo, 2007, p. 452)

Quijano (2007) shows us how after the conquest and colonial period in what currently we call Latin America, a new world order and a global power was established that still remains. Resources were concentrated and controlled by the European ruling classes. Even though colonialism has been politically defeated almost everywhere around the world, Western imperialism is the successor, where dominant groups associate to defend their social interests in countries with significant inequalities. This is where postcolonialism rises.

The 'Western' European dominators and their Euro-North American descendants are still the principal beneficiaries, together with the non-European part of the world not quite former European colonies, Japan mainly, and mainly their ruling classes. The exploited and the dominated of Latin America and Africa are the main victims. (Quijano, 2007, p. 168)

Under this logic, Western culture dominates, colonizing the imagination of the dominated, creating a postcolonialism or coloniality and the alternative would be a de-coloniality "to clear the way for new intercultural communication, for an interchange of experiences and meanings, as the basis of another rationality which may legitimately pretend to some universality" (Quijano, 2007, p. 177).

In this sense, Mignolo (2007) clarifies Quijano's purpose is not to create a new Totality that replaces the established Totality, but a none-totalitarian conception of society with heterogeneous-structural stories.

De-colonization is closely related to the concept of de-linking. This means to get rid of the rhetoric of modernity and the logic of postcolonialism. The rhetoric of modernity works through the imposition of 'salvation' (Christianity, civilization, modernization, market democracy). Therefore, de-coloniality aims to de-link from the fundamental belief of modernity: the belief in abstract universals (Mignolo, 2007).

During the 2004 meeting of the modernity/coloniality project the concerns were how to think around the Critical Theory under a de-coloniality perspective. 
The conclusion was Critical Theory had to be taken further to a project of de-linking and of being complementary with the objectives of de-colonization. To achieve this, Mignolo (2007) states Critical Theory should embrace border thinking as the method for a de-colonization of knowledge and of being. Doing this, Critical Theory would acknowledge its own Eurocentered limits "from the early version of the Frankfurt School, to later poststructuralists (e.g. Derrida) and post-modernists (e.g. Jameson)" (Mignolo, 2007, p. 484). Under this same approach, Fanon (1952) suggests the need to introduce a new perspective in the Critical Theory from the emancipation it pretended to a project of liberation and de-colonization and Anzaldúa (1987) proposes the concept of borderland to reveal the white-male-Eurocentric hegemonic epistemology of modernity.

In summary, in this formulation coloniality and postcolonialism can be defined as:

Long-standing patterns of power that emerged as a result of colonialism, but that define culture, labor, intersubjective relations, and knowledge production well beyond the strict limits of colonial administrations. Thus, coloniality survives colonialism. It is maintained alive in books, in the criteria for academic performance, in cultural patterns, in common sense, in the self-image of peoples, in aspirations of self, and so many other aspects of our modern experience. In a way, as modern subjects we breathe coloniality all the time and every day. (Maldonado-Torres, 2007, p. 243)

Therefore, going back to American cinema and its hegemonic presence around the world and particularly in Latin America as an example, we can establish two main concerns. First, what are the characteristics of American cinematic texts in terms of their links with coloniality narrative; this means are these films reproducing coloniality premises through the way they address cultural patterns, image of peoples, aspirations of self. Second concern would be if the academic performance mentioned by Maldonado-Torres around this type of narratives is being developed mainly from coloniality and Northern scenarios. Countries, cultures, societies that have been influenced by American cinema and its coloniality storytelling are analyzing and studying these texts or, on the contrary, even the analysis of these discourses is being produced under a coloniality dynamic?

\section{Media and De-colonialism}

Shome (2016) states scholars have not even theorized media adequately as a postcolonial issue. Therefore, one could say if postcolonialism has not been seen as an issue by most media scholars, then it is impossible for them to reach the point of proposing a de-colonialism of media studies.

It is (...) a matter of recognizing the current received history of media in the West as being linked to colonialism and postcolonial inequalities. It is a matter of acknowledging how this history may have suppressed other epistemes of media and communication from gaining visibility in flows of everyday and academic knowledge. (p. 3) 
Shome assures not only the production of media has been concentrated under coloniality logics, but also the analysis and academic study of the media. Shome proposes an interruption of the postcolonial history of the media and calls for a de-colonization of media studies. Shome also points out how postcolonial studies have not addressed sufficiently media, technology, and popular culture as important elements in the process of understating coloniality.

Park \& Curran (2000) describe this tendency as "a self-absortion and parochialism of much of Western-based media theory" (p. 2). Curran \& Park were convinced this predisposition had to be broken since they observed how always rich Western societies were producing theory around media and society. In this sense, Featherstone (2013) includes a new argument in the discussion pointing how during the 1990s postcolonial studies did not give attention to popular culture "[a]nd more recent reassessments have generally maintained this inattention" (p. 2). Featherstone analyzes how even recent postcolonial studies do not extend their areas of debate to popular materials.

Fernández (1999) exposes a similar thought stating that postcolonial studies have been concentrated in European imperialism and its effects ignoring media as a key element in this relationship between colonizers and colonized. In fact, Fernández reminds us how the process of colonization of knowledge theorized by Dussel, has been based hugely on media, first the book, then film, television and now digital media. Therefore, it appears to be incomplete a vision of postcolonialism that does not include media and popular culture as elements for analyzing this phenomenon.

However, Willems (2014) warns us about the difference between merely expanding the empirical work on the field to global South or non-Western territories in contrast to building knowledge that actually recognizes and aims to retrieve "the broader politics of knowledge production which has contributed to the active marginalization of knowledge produced outside the Anglo-American axis" (p. 417). In other words, new theoretical approaches that stand away from coloniality logics should be brought to this debate.

Postcolonial studies have paid minimal attention to the role played by media in the context of transnational, colonial, and nationalist relations. It has also paid limited attention to the ways in which media cultures intersect in, and inform, many contemporary postcolonial sensibilities. (Shome, 2016, p. 1)

Taking into consideration all these concerns, the arguments of this research are: first, it is relevant to include coloniality or postcolonialism as an essential category in the study of the relationship between Northern cinema and global South. As we have seen, media in general have not been observed academically under the postcolonialism insight and it is extremely pertinent to start introducing Northern popular culture products such as films in this discussion. Second, it appears necessary to start proposing from these researches de-colonized academic frameworks that may contribute in the process of imagining and conceiving an authentic de-colonized worldwide filmography that helps de-linking the colonization chains. Even though some few scholars have already shown us a path (Montez de Oca, 2012; Thussu, 
2009; Wang, 2011a, 2011b) after describing this academic panorama it appears hugely relevant to start analyzing postcolonial cinematic narratives from the border thinking proposed by Mignolo with much more consistency and visibility. Bringing back the concern of American cinema hegemony around the world, as we already mentioned it is necessary to explore and study these narratives that have a starring presence in our cultural lives under this postcolonial and de-colonial logic. In addition to this, it is also crucial to start building a completely new theorization around media, in this case cinema, and reflect around the role played by filmmaking in the perpetuation of postcolonial relations. As we have seen Northern cinema has been a cultural model in global South. Therefore, it would be extremely helpful to start proposing from the academic universe, a serious and scientific reflection regarding the urge of creating de-colonized filmic narratives.

\section{SPORT Films}

The next question is why American sport films could be a convenient genre for analysis under the perspective of social communication and creator of cultural models expressed by Tudor and through the epistemological lens of Critical Theory and de-colonization. First thing we need to clarify is why sport films can be considered a cinematographic genre itself. Cinema scholar Bruce Babington (2014) has studied this relationship between cinema and sport and has defined this type of narratives.

Against the claim that sports films lack such generic attributes as a typical miseen-scène, a characteristic style, and auteurs, there are various answers: That the typical mise-en-scène is the sports stadium or games playing site, the 'field of dreams', that a major part of the genre's iconography consists of the materials of and surrounding sport, and that to define a genre by whether or not highly regarded individual directors have made careers in it is eccentric. (p. 4)

Babington (2014) establishes five categories for studying American sport films. This research has centered around one of them: American sports as a symbol of Americanness, with success in them a means of moving from society's margins to its center.

If we go back to the official storyline of The Blind Side we can see it defines Mike as the main character whose objective is to become an NFL player: we can clearly see the sport drive in the storyline. Taking into consideration the definitions established by Babington (2014), we can see how The Blind Side can perfectly be considered a sport film. The sport stadiums and the practice fields are key locations in the story. The sport iconography is present all over the film; in fact, the title talks about an American Football term related to a game strategy. Uniforms, matches, stadiums and practices are main part of the film. In addition, we can find The Blind Side appears in the sport films category of most cinema specialized websites (Imdb, Filmsite, Boxofficemojo).

Now, going back to the debate of American sport films seen under a Critical Theory and postcolonial perspective, if we observe in detail, that first category 
described by Babington (2014) could perfectly be considered as postcolonial characteristics. Americanness is related to a certain way society should work where success can take you from the margins to the spotlight. Here we can talk about the American Dream and how this concept has been massively spread through popular products convincing other cultures and societies success is a key vehicle and goal for individuals. Montez de Oca (In Press) argues that in sport films, particularly football films, the American Dream is portrayed under stories that celebrate a characters' transformation through his commitment and sacrifice.

\section{METHODOLOGY}

This research has taken this category proposed by Babington (2014) for developing a textual analysis of The Blind Side. The study has focused in the last sequence of the film to analyze the last message the narrative sends to the spectators, as well as to use it as a micro-analysis of the film as a whole. This examination has concentrated on the narrative of the sequence and has not approached any filmic or formal attributes of it, only the events told in the segment itself. At this point, it is important to mention textual analysis appears to be a relevant methodology for this research due to the importance of context for this research method. In the attempt of trying to analyze a text, it is essential to ask two crucial questions: interpreted by whom and in what context (McKee, 2001). In this sense, as it has been stated until now, this analysis is situated in a global South context and the perspective of the analysis is under a postcolonial approach. This is the specific framework of this research. McKee (2001) states that standardized procedures are not important for textual analysis due precisely to the importance of context for this research method. According to this, the research has chosen the category designed by Babington for the textual analysis.

\section{RESULTS}

The Blind Side: A Critical Postcolonial Textual Analysis

The official storyline of The Blind Side published on the specialized film website Imdb, says: "is the story of Michael Oher, a homeless and traumatized boy who became an all-American football player and first round NFL draft pick with the help of Leigh Ann Tuohy, a caring woman and her family".

\section{Analysis Category}

American sports as a symbol of Americanness, with success in them a means of moving from society's margins to its center.

Mike Oher clearly lives in the margins of society before becoming a sportsman: no family, no friends, and no social attributes. However, Oher moves to 


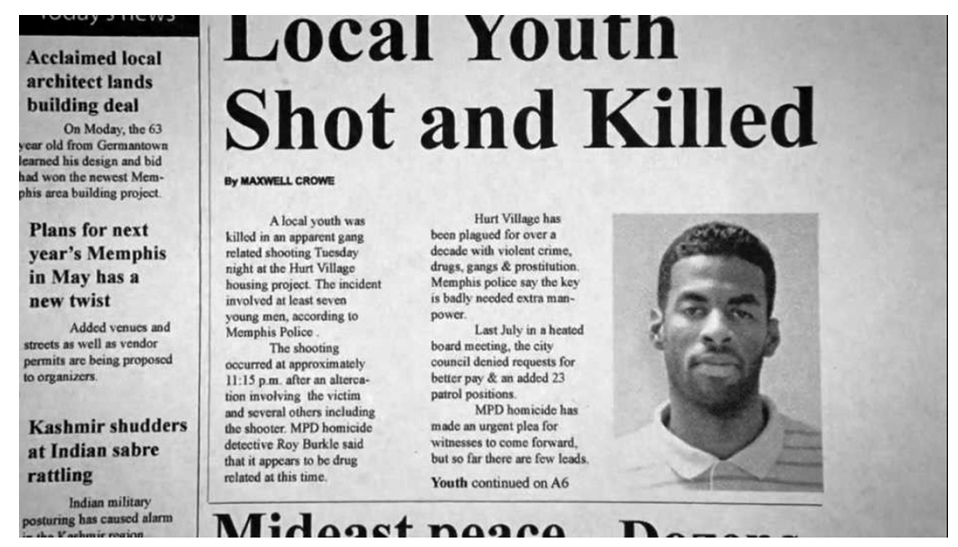

Figure 1. Final sequence from The Blind Side.

News from Mike's friends being shot.

the center of the society through sport, that is his vehicle. This concept is reinforced towards the end of the film. There, we can see a sequence where we can listen a voice over by Leigh Anne where she talks about a story she had found on the newspaper. The news covers the death of one of Mike's neighbors during a gang conflict. These images are intercut with a shot of Mike smiling and walking to his university college through the parallel film montage technique. The message here is clear: Football saved Mike's life (see Figure 1, 2, and 3).

If we analyze this category from a postcolonial perspective, we can state the film's ending underlying message is sport, in this case American football, is what will take an individual out of the marginalized society to success and to the spotlight. The film's ending enounces the most important aspect in life is to succeed; otherwise the subject will be just part of an invisible and silenced mass. Here we can see the reproduction of those postcolonial dominant groups described by Quijano. If an individual does not belong to these dominant groups, is absolutely marginalized. (2008).

This category is very related to the feel-good morality expressed by Kusz

[A]merican audiences' purported desire to see 'feel-good' morality tales that express "universal" existential themes while simultaneously appearing to confirm the "truth" of dominant American mythologies like individualism, meritocracy, hard work and personal perseverance displayed through the "authentic" stories of heroic athletes, many of which are either "based on" or "inspired by" a true story. (p. 210)

According to its producers, The Blind Side is a film "based on a true story" and tells the events of a heroic athlete-Mike Oher-who enacts individualism, leaves his social and family background behind and becomes a successful sportsman. The American postcolonial mythology of pursue of success as the key to happiness is very present here. 


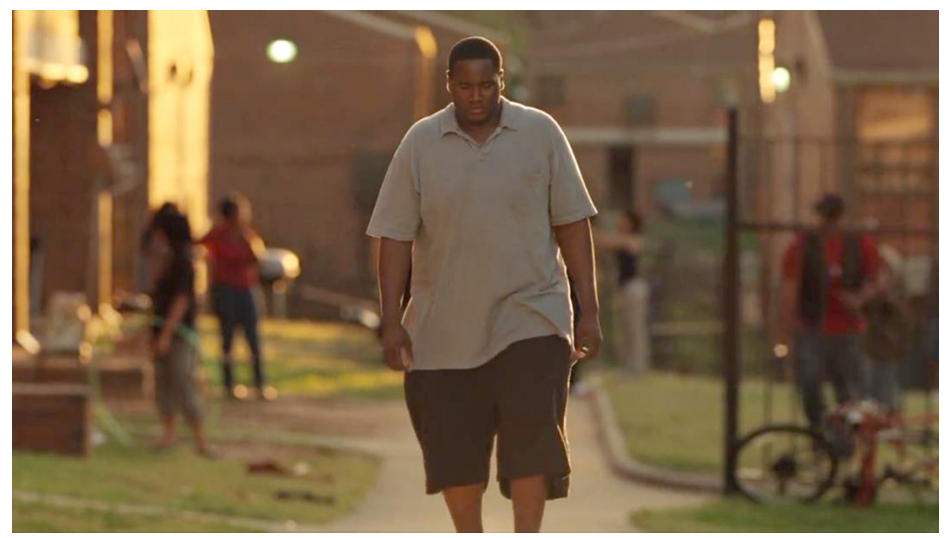

Figure 2. Final sequence from The Blind Side. Here we can see Mike's neighborhood and social context before moving out to the Tuohy's home.

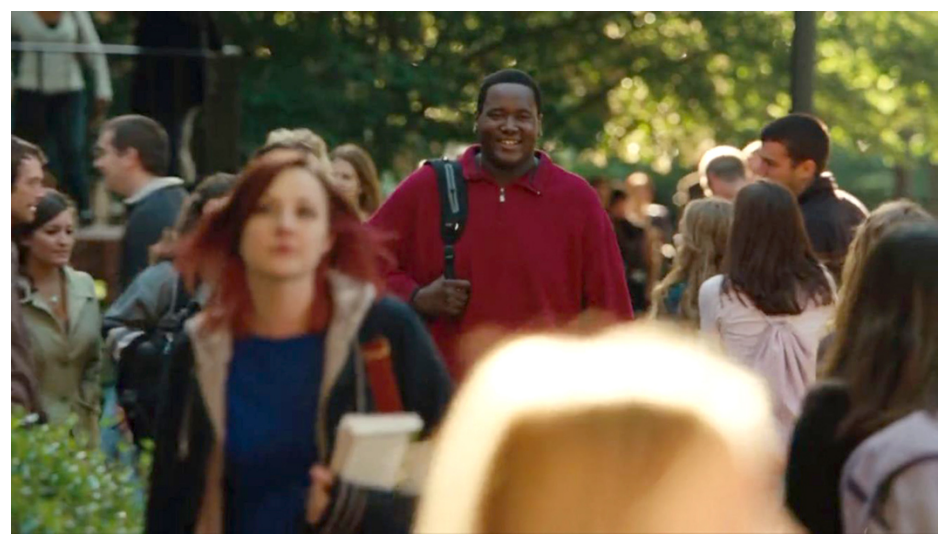

Figure 3. Final sequence from The Blind Side. Mike on his way to Ole Miss University where he was admitted.

\section{CONCLUSIONS}

The final sequence of The Blind Side perfectly fits the model presented in this research that aims to show how American sport films have a postcolonial ideological agenda underneath the story itself. It is important to analyze what are the messages and the premises lying under such a powerful medium like moving image narratives. It is extremely relevant to assume this type of texts as social communicators, as cultural models and not just as entertainment.

Let us go back to the beginning of this discussion and stand again on the Critical Theory territory. It is important to remember these words by Adorno and Horkheimer (2002): "the defrauded masses today cling to the myth of success still 
more ardently than the successful. They, too, have their aspirations. They insist unwaveringly on the ideology by which they are enslaved" (p. 106). Seventy years afterwards, these words are still perfectly valid.

Whannel (2008) stated it clearly:

These films are rooted in an ideology of competitive individualism which is a distinct product of capitalism as it developed in the United States of America. So while women, Jews, Afro-Americans and British Asian girls all find fulfilment through the narrative journey of these Films, it tends to be within the terms of the competitive individualist ideology. (p. 195)

The main conclusion of this research is the final sequence of The Blind Side reproduces postcolonial premises that emphasize the importance of success as the vehicle for moving from the margins of society to its center.

Recibido: 10 de septiembre de 2019, aceptado 14 de enero de 2020 


\section{REFERENCES}

Antonio, Robert J. \& Bonanno, Antonio (2000). “A New Global Capitalism? From 'Americanism and Fordism' to 'Americanization-Globalization”. American Studies, 41(2/3): 33-77.

Anzaldúa, Gloria (1987). “Borderland/La Frontera”, in The New Mestiza. Aunt-Lute: San Francisco: p. 7.

Babington, Bruce (2014). Sports Film. The Games People Play. New York: Wallflower Press Book. Columbia University Press.

BAKer, Aaron (2003). Contested Identities: Sports in American Film. Champaign: University of Illinois.

Box Office Mojo. The Blind Side (online). http://www.boxofficemojo.com/movies/?id=blindside. htm, last access August 30, 2019.

Bywater, Tim \& Sobchack, Thomas (1989). Introduction to Film Criticism: Major Approaches to Narrative Film. New York: Longman.

Carrington, Ben (2010). Race, Sport and Politics: The Sporting Black Diaspora. Thousand Oaks: Sage.

Cashmore, Ellis (2008). "Chariots of Fire: Bigotry, Manhood and Moral Certitude in an Age of Individualism”. Sport in Society, 11:2-3: 159-173.

Dussel, Enrique (2002). "World-system and Trans-modernity". Nepantla. Views from South, 2, no. 3: 221-245.

Featherstone, Simon (2013). "Postcolonialism and Popular Culture", in G. Huggan (ed.), The Oxford Handbook of Postcolonial Studies. Oxford: Oxford University Press.

Fernández, María (1999). “Postcolonial Media Theory”. Third Text, 13(47): 11-17.

Fanon, Frantz (1952). Peau Noire, Mosques Blancs. Paris: Editions du Seuil.

Follows, Stephen (2017). How Important is International Box Office to Hollywood? (online). https://stephenfollows.com/important-international-box-office-hollywood/, last access August 30, 2019.

Giardina, Michael (2003). “Bending it like Beckham' in the Global Popular”. Journal of Sport and Social Issues, 27:1, 65-82.

Horkheimer, Max \& Adorno, Thedor (2002). Dialectic of Enlightenment. Philosophical Fragments. Stanford: Stanford University Press.

IMDв. The Blind Side (online). https://www.imdb.com/title/tt0878804/?ref_=fn_al_tt_1, last access August 30, 2019.

Jaramillo, Rubén (2005). “Origen y Destino de la Teoría Crítica de la Sociedad”. Revista Internacional de Filosofía Politica: 5-16.

King, Richard \& Leonard, David (2006). Visual Economies oflin Motion. New York: Peter Lang.

Kusz, Kyle (2008). "Remasculinizing American White Guys In/Through New Millenum American Sport Films". Sport in Society, 11:2-3: 209-226.

Maldonado-Torres, Nelson (2007). "On the Coloniality of Being”. Cultural Studies, 21:2: 240- 270.

McKee, Alan (2001). “A Beginner’s Guide to Textual Analysis”. Metro magazine, 127-128: 138-149.

Mignolo, Walter (2007). "Delinking”. Cultural Studies, 21:2-3: 449-514.

Montez de Oca, Jeffrey (2012). "White Domestic Goddess on a Postmodern Plantation: Charity and Commodity Racism in 'The Blind Side'”. Sociology of Sport Journal, 29: 131-150. 
Neal, Mark Anthony (2006). New Black Man. New York: Taylor \& Francis.

Montez de Oca, Jeffrey (2013). "Sport as Social Institution: Football Films and the American Dream”, in J-A. Sutherland \& K. Feltey (eds.), Cinematic Sociology: Social Life in Film (2nd ed.). Los Angeles: Pine Forge Press.

Pardo, Alejandro (1998). “Cine y Sociedad en David Puttnam”. Comunicación y Sociedad, XI, 2: 53-90.

Park, Myung-Jin \& Curran, James (eds.). (2000). De-westernizing Media Studies. New York: Routledge.

Quijano, Aníbal (2007). “Coloniality and Modernity/Rationality”. Cultural Studies, 21:2-3: 168-178.

Rotten Tomatoes. The Blind Side (online). http://www.rottentomatoes.com/m/1212694-blind_side/, last access August 30, 2019.

Santos, Boaventura de Sousa (2016). "Epistemologies of the South and the Future". Europeansouth Journal, 1: 17-29.

Shome, Raka (2016). "When Postcolonial Studies Meets Media Studies”. Critical Studies in Media Communication: 1-19.

Thussu, Daya Kishan (ed.) (2009). Internationalizing Media Studies. New York: Routledge.

Thyberg, David (2017). The Average Starting Football Salary (online). https://careertrend.com/ the-average-starting-football-salary-13637654.html, last access August 30, 2019.

Tudor, Andrew (1975). Cine y Comunicación Social. Barcelona: Gustavo Gili.

WANG, Georgette (ed.) (2011a). De-westernizing Communication Research. New York: Routledge.

WANG, Georgette (2011b). “Beyond De-westernizing Communication Research: An introduction”, in G. Wang (ed.), De-Westernizing Communication Research (pp. 1-18). New York: Routledge.

Whannel, Garry (2008). "Winning and Losing Respect: Narratives of Identity in Sport Films". Sport in Society, 11 2-3: 195-208.

Willems, Wendy (2014). "Provincializing Hegemonic Histories of Media and Communication Studies: Toward a Genealogy of Epistemic Resistance in Africa”. Communication Theory, 24: 415-434. 
